\title{
PHYTOCHEMICAL COMPOUNDS AND PLANT PRODUCTS THAT STIMULATE METHANOGENIC PROCESSES OF ANAEROBIC FERMENTATION BY MICROORGANISMS
}

\author{
Valentin Bobeică, Victor Covaliov, Vladimir Nenno, Olga Covaliova
}

Research Center of Applied and Ecological Chemistry of the Moldova State University, 60, Mateevici str., MD 2009, Chishinau, Republic of Moldova

\section{Summary}

For the first time, phytochemical stimulants that intensify the process of fermentation and increase the methane content in the produced biogas were applied in the technology of obtaining biogas through anaerobic fermentation. The residual marc obtained from distillation of bio-alcohol from nonstandardized raw-materials has served as experimental substrate. A series of substances consisting of various derivatives of phytochemical compounds such as flavonoids, tannins, mono-, di and triterpenoids, sterols, triterpene- and sterol- saponins, carotenoids that manifested themselves as more active stimulants of methane production than the diterpenoid sclareol, or triterpenoids squalene and betulinol, all from the terpenic compounds group were tested experimentally. The laboratory experiments that were performed have applied these three compounds to the anaerobic fermentation environment in concentrations varying between $10^{-5}-10^{-3} \%$ by mass of substrate, which demonstrated an increase of the ratio of fermentation up to 2-3 times and an increase of the methane content from $50-60$ up to $80 \%$. Monoterpenoids, while applied in same quantities, have manifested a reduced intensification of anaerobe fermentation. The investigated flavonoids, tannins and saponins applied in similar conditions of testing have caused the reduction of the content of methane in biogas emissions.

Keywords: phyto-stimulants, agro-industrial residues, biogas, biomethane.

\section{Introduction}

The intensification of the process of anaerobic fermentation and increase of the yield of methane in the emissions of produced biogas represents a problem that becomes more and more important, as long as the biogas production from renewable materials of vegetal and animal origin and its importance as an energy agent becomes more important and attractive in the conditions of promotion of the concept of green energy and principles of sustainable development. Even though the biogas is produced from relatively inexpensive specially cropped vegetal materials and even more inexpensive vegetal and animal residues, these raw materials are not easily affordable from the point of view of costs of production. Promotion of biogas production in conditions of real market requires increased efficiency is facing of a series of entanglements that are related to:

- continuous assurance of sources of raw material, 
- maintenance of optimal values of $\mathrm{pH}$ in the fermentation environment,

- augmentation of the yield of methane in the produced biogas,

- purification of obtained biogas, etc.

On the one hand, the industrial technologies of anaerobic fermentation and biogas production that are used nowadays are based on application of vegetal materials cultivated especially for these purposes (eg. corn) or their mixtures with agro-industrial residues, animal manure etc. The cultivation of plants for energy purposes has several fundamental disadvantages which are related to removal of agricultural lands that were meant, or were supposed to be used in the future, for the assurance with food for population and high emerging expenses of cultivation. Another problem which causes a disadvantage for the anaerobic biogas production is the relatively low content of methane in the exhausts. Is is well known that biogas obtained in normal conditions of anaerobic fermentation contains approximately $50-70 \%$ of methane, being accompanied by $30-40 \%$ of $\mathrm{CO}_{2}$, that causes the decrease of caloric value of biogas, as well as $1-2 \%$ of $\mathrm{H}_{2} \mathrm{~S}$ and $\mathrm{NOx}$ that are ecotoxic and confer corrosive properties to the biogas, while the natural gas contains more than $99 \%$ of methane. In such conditions a consistent share of expenses of anaerobic biogas production goes to purification of gas from accompanying gases, which is a process that requires a relatively high amount of reagents and energy, generating along the way new environmental problems.

In order to reduce the utilization of dedicated plants in the industry of biogas their partial substitution of raw materials with various wastes such as industrial and household residues containing increased amounts of biodegradable organic products takes place.

Worldwide there are performed multiple investigations concerning the increase of methane in the biogas [1] through controlled temperature regimes, biodigestion pressure regimes, utilization of certain more efficient species of plants, stimulation of microorganisms' activity with nutrients, application of synthetic chemical catalysts, utilization of special phytomass in the fermentation environment such as amarant [2] etc. The increase of methane yield in the produced biogas through anaerobic fermentations increases its caloric capacity and reduces the expenses related to $\mathrm{CO}_{2}$ removal.

The most effective accessible process, currently applied at industrial level, that assures the increase of methane content in some cases up to $80 \%$, is through utilization of certain anaerobic microorganisms strains that are able to augment the methanogenesis [3]. However, identification, production and utilization of these microorganisms proved to very expensive.

The above mentioned aspects had grounded the scope of current paper, which consist in investigation and identification of some new technological approaches for anaerobic fermentation and production of biogas containing increased amounts of methane and, respectively, improved caloric value that requires less additional natural resources and less supplementary treatment in the phase of biogas conditioning. 
2. Phytochemical intensification of methanogenesis in the process of anaerobic fermentation of some liquid agroindustrial residues (results and discussions)

In accordance with the expressed scope, the tasks of current work are concentrated on the research of perspectives of increasing of the efficiency of biogas production from liquid agroindustrial residues, intensification of the process of anaerobic fermentation and increase of methane content in the biogas.

At the beginning, our attention in the process of selection of raw material was concentrated on a less investigated agroindustrial residue which is a sludge generated during bioethanol production from agricultural products. The diversity of such residues is high since they are constituted of wine materials of poor quality, potatoes, fruits, legumes, nonstandardized cereals etc. The liquid residues generated during bioethanol production, as well as those generated during processing of milk, meat, fruits, legumes, residues from sugar factories and beer makers contain between $4-10 \%$ of organic substances that makes them suitable for application as war materials for biogas production.

At the same time the above mentioned liquids represent a potential threat for the environment. Being discharged into natural water bodies these liquids destabilize the established equilibria and impact the quality of water and affect various species of hydrobionts, microflora and microfauna of the lower water courses and lakes. Additionally, the contaminated waters are not suitable for irrigation. Hence, this is one of the origins of the problem of utilization of water from the affected water bodies [4]. In the Republic of Moldova the bioethanol processing industry is the most important source of liquid residues that contain increased amounts of natural organic compounds. The mentioned liquids (marc from distillation) contain up to $8-10 \%$ of dry residues containing oligo- and polysaccharides, polyphenols, organic acids, in less amounts organic substances of proteic origin and demonstrate high levels of chemical oxygen demand (COD) and biological oxygen demand.

The wastewaters containing the marc from bioethanol producers overload the municipal treatment facilities, and represent an economic burden for the mentioned industry, and these problems still seek a solution. The samples of marc that were investigated demonstrated a COD level of 2800-2900 mgO2/l and BOD level of $1800-1900 \mathrm{mgO}_{2} / \mathrm{l}$. Exposure of the investigated marc samples to anaerobic fermentation has caused the reduction of this parameters below $20 \%$ in comparison with initial value of both indicators.

\section{Maintenance of optimal levels of pH}

The marc of winemaking origin contains organic acids that are responsible for the acidity of the substrate and has a pH value around 3.5-5.5 which is not favourable for optimal activity of methanogenic microorganisms, since the later ones require the $\mathrm{pH}$ of 6.5-7.5. In order to maintain an optimal $\mathrm{pH}$ of the fermentation environment several methods developed in the frames of our previous investigations where applied. The procedure consists in 
electrochemical neutralization of the acidity of the marc through electrochemical alkalinization in an cathodic chamber of an electrolyzer (Patent nr. 2017 MD, $\mathrm{BOPI}, \mathrm{nr} .10,2002)$. An alternative procedure consists of neutralization of the hot marc $\left(70-85{ }^{\circ} \mathrm{C}\right)$, which is removed from distillation, with a calcareous powder of residues generated during excavation of chalk. The marc is treated with small batches of calcareous powder until the $\mathrm{pH}$ level 6-7 is achieved, followed by ulterior removal of suspended matter through sedimentation or centrifugation and subsequent reduction of temperature to a level optimal for fermentation (Patent nr. 2017 MD, BOPI, nr.10, 2002). In case of this research which is further elaborated in the current work, the photochemically intensified process of methanogenesis occurs more efficiently in mesophile conditions at the temperature of $32-33^{\circ} \mathrm{C}$.

\section{Testing of phytochemical compounds}

The test of phytochemical intensification of the process of anaerobic fermentation was carried out with respect to a series of phytochemical compounds produced by various vegetation species having various chemical properties: flavonoids (a flavonoid complex of silymarin consisting of three compounds: silybin, silychristin, silychristin silydianin), tannins, terpenoids (monoterpenoid monocyclic alcohols limonene and menthol, bicyclic diterpenoid sclareol, triterpenoids acyclic hydrocarbon squalene and pentacyclic alcohol of the group betulinol lupane), tetraterpenoid ( $\beta$-carotene extract) saponins (glycosides furastanol tomatosyde and triterpenic hipsosyde). The testing was carried out through addition of various concentrations of the above mentioned phytochemical compounds to the substrate exposed to anaerobic fermentation. The measurements were performed on samples collected in a gazgolder and included the volume of biogas emissions as dependence of time (the rate) and chromatographic analysis of the content of methane and carbon dioxide in the obtained biogas. The preliminary analysis of this measurement allowed us to conclude that the majority of terpenic substances manifest at a certain extent ability to intensify methanogenic process. The triterpenic squalene and betulinol as well as diterpenoid sclareol were among the most active promoters. Monoterpenoids and the extract enriched with tetraterpenoid $\beta$-carotene added in similar concentrations had lower potential of intensification of the anaerobic fermentation. Flavonoids, tannins and saponins used in the investigation in similar conditions have caused the decrease of the amount of methane in biogas emissions.

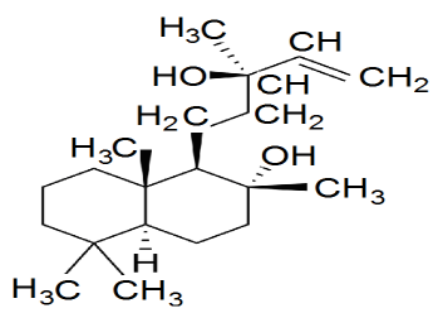

Sclareol Betulinol
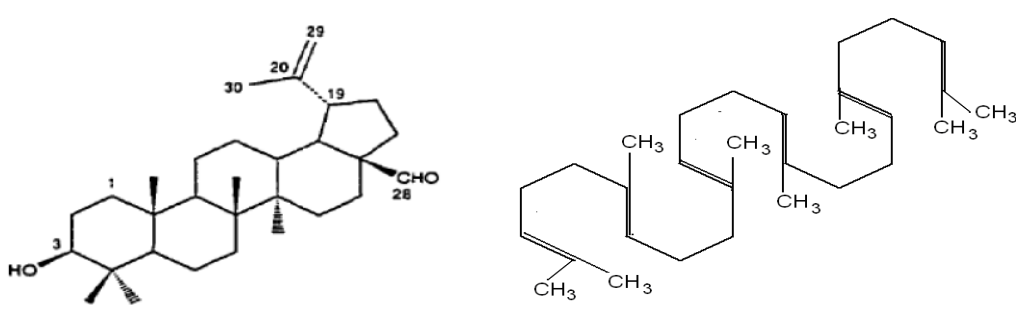

Squalene

Figure.1 Phytochemical compounds that stimulate the methanogenic fermentation of agroindustrial wastes 
Further investigations were focused on two compounds that in previous investigations were the most active promoters of methanogenic fermentation, and namely - squalene and betulinol [5] .

In order to facilitate the homogenous addition of phytostimulation agents to the fermentation medium and increase their bioavailability for methanogenic microorganisms in the digester, three preparations containing both of the above mentioned phytochemical compounds: STIM-CH 4 , BIOSTIM ( I, II )- $\mathrm{CH}_{4}$ were developed, which in the experimental environments demonstrated a 2-3 fold increase of the ratio of fermentation processes and increased the amount of methane in the biogas samples from $60 \%$, corresponding to regular conditions (no additives) up to $80-90 \%$ (figure 2 ).

The data provided in the figure 2 shows that as a result of application of the most effective concentration $\left(4.10^{-4} \%\right.$ by mass of substrate) of the preparation containing STIM-CH 4 based on acyclic iso-propenoic triterpenoid squalene the intensification of the process of anaerobic fermentation expressed as the increase of the specific ratio $\left(\mathrm{m}^{3}\right.$ biogas $/ 24 \mathrm{~h} / 1 \mathrm{~m}^{3}$ substrate) of biogas emission by approximately 2.2 times and of the methane content by approximately 1.4 (up to $85.4 \%$ ).

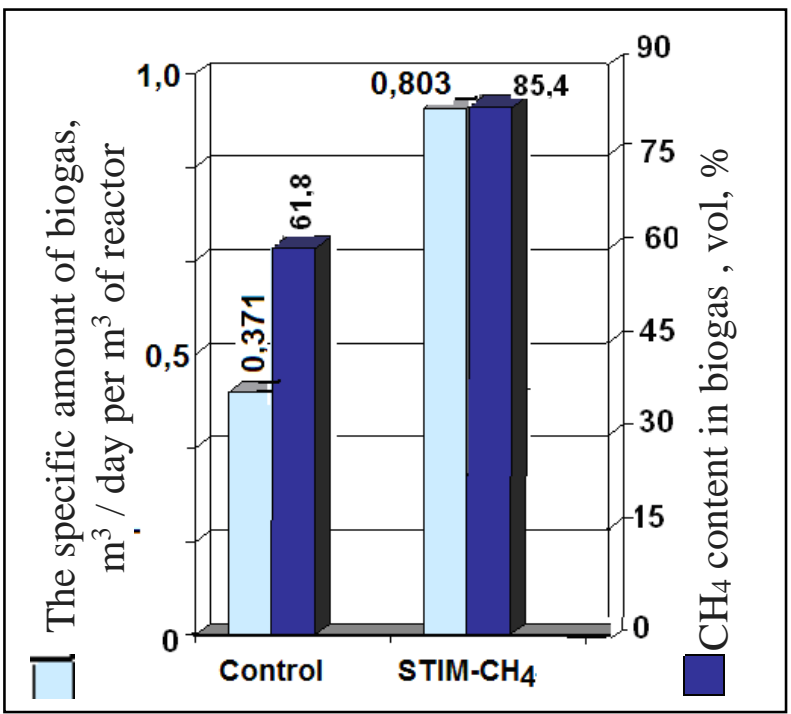

Figure 2. The effect of microcomponent STIM-CH 4 on the emission of biogas and the methane content in the process of anaerobic fermentation of marc from winemaking (content of microcomponent $-0.0004 \%$ by mass of substrate)

Similar effect of methanogenesis was obtained also in the case of another preparation, BIOSTIM I-CH 4 which is based on the triterpenic alcohol of the lupane-betulinole group. The difference in comparison with $\mathrm{STIM}_{-} \mathrm{CH}_{4}$ constituted in a higher rate of emission of biogas. The last one exceeded the control ratio by 3.4-3.7 times, while the STIM-CH $\mathrm{CH}_{4}$ provided a 1.5-1.7 times increase. The combined application of these preparations in an optimal ratio (the preparation BISTIM- $\mathrm{CH}_{4}$ ) demonstrated a synergistic effect (tab. 1) thus, essentially improving the efficacy of the process of phytostimulation of methanogenic fermentation. 
Table 1. Effect of the application in the anaerobic fermentation of marc of micro-components BIOSTIM II $-\mathrm{CH}_{4}$ biogas emissions and methane content

\begin{tabular}{|c|c|c|c|c|c|c|c|c|c|}
\hline \multirow{2}{*}{\multicolumn{2}{|c|}{$\begin{array}{l}\text { Time of anaerobic } \\
\text { fermentation }\end{array}$}} & \multirow{2}{*}{\multicolumn{2}{|c|}{ Control variant }} & \multicolumn{6}{|c|}{ content of BIOSTIM II - $\mathrm{CH}_{4}$} \\
\hline & & & & \multicolumn{2}{|c|}{$0.001 \%$} & \multicolumn{2}{|c|}{$0.00025 \%$} & \multicolumn{2}{|c|}{$0.0005 \%$} \\
\hline $\begin{array}{c}\text { Time } \\
\text { interval }\end{array}$ & $\begin{array}{c}\text { hou } \\
\text { rs }\end{array}$ & $\begin{array}{c}\text { Volume } \\
\text { of biogas } \\
\text {, ml }\end{array}$ & $\begin{array}{l}\text { Rate } \\
\mathrm{ml} / \mathrm{h}\end{array}$ & $\begin{array}{c}\text { Volume, } \\
\text { ml }\end{array}$ & $\begin{array}{l}\text { Rate, } \\
\mathrm{ml} / \mathrm{h}\end{array}$ & $\begin{array}{c}\text { Volume, } \\
\text { ml }\end{array}$ & $\begin{array}{l}\text { Rate, } \\
\mathrm{ml} / \mathrm{h}\end{array}$ & $\begin{array}{c}\text { Volume, } \\
\text { ml }\end{array}$ & $\begin{array}{l}\text { Rate, } \\
\mathrm{ml} / \mathrm{h}\end{array}$ \\
\hline $0-18$ & 18 & 100 & 5.6 & 250 & 13.9 & 325 & 19.1 & 300 & 16.7 \\
\hline $19-25$ & 7 & 40 & 5.5 & 75 & 10.7 & 75 & 10.7 & 100 & 14.3 \\
\hline $26-45$ & 20 & 110 & 5.5 & 50 & 2.5 & 0 & 0 & 0 & 0 \\
\hline $46-69$ & 24 & 120 & 5.0 & 0 & 0 & 0 & 0 & 0 & 0 \\
\hline $70-93$ & 24 & 75 & 3.1 & 0 & 0 & 0 & 0 & 0 & 0 \\
\hline \multicolumn{2}{|c|}{ Total } & 445 & 4.8 & 375 & 8.3 & 400 & 16.0 & 400 & 16.0 \\
\hline \multicolumn{2}{|c|}{$\begin{array}{c}\text { Content of } \\
\text { methane în } \\
\text { biogas, vol. \% }\end{array}$} & \multicolumn{2}{|c|}{69.2} & \multicolumn{2}{|c|}{81.8} & \multicolumn{2}{|c|}{92.8} & \multicolumn{2}{|c|}{93.3} \\
\hline
\end{tabular}

The data obtained and presented in the table 1 regarding the synergetic effect of stimulation of the anaerobic fermentation by the preparation BISTIM II-CH based on the optimal ratio combination of squalene and betulinol are compliant with the preliminary data obtained for chemical compounds applied in their pure form [5]. The later ones induce an increase of the content of biomethane in the biogas up to $93.3 \%$ in the case of the most effective concentration of the preparation $\left(5 \cdot 10^{-5} \%\right)$ in the substrate exposed to anaerobic digestion. This result exceeds by 1.35 times the results obtained in control samples and corresponds to a biomethane content that is by $8 \%$ bigger than the results obtained during treatment with the STIM-CH4 preparation that is based on squalene. Even more spectacular proved to be the values of the ratio of emission of biogas. It exceeds by 3.3 times the control results of the control sample in which the process of fermentation was not over even after four days of fermentation, while in the tested sample the biogas emission has expired after one day of fermentation.

The intensification of the activity of methanogenic organisms in the presence of investigated substances could be associated, to a certain extent, with their biological properties that depending on real circumstances could manifest inhibiting antioxidant properties of lipids peroxidation, membrane protection or membrane stabilization properties, antimutagenic properties or can contribute to the formation of resistance against hypoxia. It is considered that in biochemical reactions squalene can have the role of water oxygen binding agent and transporter of oxygen to the biologic tissues, therefore assuring the anti-hypoxic effect, which is very important for the assurance of survival of methanogenic microorganisms. 


\section{Methods and materials}

The substrates exposed to digestion (table 2) consisted of the marc obtained as a result of distillation of bioethanol from wine-making materials and nonstandardized cereals provided by a local industrial enterprise of high capacity of production. The $\mathrm{pH}$ level of the marc was corrected to 6-7 by electrochemical neutralization of its acidity in the cathodic chamber of an electrolyzer (Patent $\mathrm{nr}$. $2017 \mathrm{MD}, \mathrm{BOPI}, \mathrm{nr} .10,2002$ )

Table 2. Several chemical and micro-biochemical characteristics of the winemaking marc used as substrate for methanogenic fermentation

\begin{tabular}{|c|c|c|c|c|c|c|c|c|}
\hline Waste & $\mathbf{p H}$ & $\begin{array}{c}\text { Humidity, } \\
\%\end{array}$ & $\begin{array}{c}\text { Dry } \\
\text { residue c } \\
, \%\end{array}$ & $\begin{array}{c}\mathrm{C}, \\
\% \text { of } \\
\text { native } \\
\text { mass }\end{array}$ & $\begin{array}{c}\mathbf{C}, \\
\% \text { dry } \\
\text { residue }\end{array}$ & $\begin{array}{c}\mathrm{COD,}, \\
\mathrm{mgO}_{2} / \mathrm{l}\end{array}$ & $\begin{array}{c}\mathrm{BOD}_{5}, \\
\mathrm{mgO}_{2} / 1\end{array}$ & $\begin{array}{c}\text { Heterotrophi } \\
\mathbf{c} \text { bacteria } \\
\mathrm{CFU}^{*} \cdot 10^{6} / \mathrm{ml}\end{array}$ \\
\hline $\begin{array}{c}\text { Marc from } \\
\text { distillation of } \\
\text { bioethanol }\end{array}$ & $\mathbf{5 . 4 0}$ & $\mathbf{9 1 . 8 2}$ & $\mathbf{8 . 1 8}$ & $\mathbf{4 . 3 0}$ & $\mathbf{4 9 . 3}$ & $\mathbf{2 8 1 5 0}$ & $\mathbf{1 8 2 0 0}$ & 7.39 \\
\hline
\end{tabular}

${ }^{*} \mathrm{CFU}$ - colonies forming units

\section{Laboratory testing}

Researches of the influence of biologically active substances on the process of methanogenesis were carried out on four units of a specially designed bioreactor [6, 7]. The equipment consists of a bench-scale bioreactor placed in a thermostatically $\left(\mathrm{t}^{0}=32-33^{\circ} \mathrm{C}\right)$ controlled volume, a series systems of provision of sludge, purified water and preparations, depending on the needs, and for removal and control the volume of obtained biogas. The total volume of the bioreactor is $5000 \mathrm{~cm}^{3}$, the useful volume $-3500 \mathrm{~cm}^{3}$. To ensure additional surface for the development of immobilized methanogenic bacteria, the grapevine rods have been introduced in the bioreactor, with the total package surface of $8000 \mathrm{~cm}^{2}$ [3]. The nutrition mixture with milk and sugar was gradually substituted by the mixture of alcohol distillery industry grains $(60 \%)$ and farmyard manure (40\%).

Cultivation and adaptation of anaerobic microorganisms was performed, following the well-known procedure of sludge inoculation applied at the Chisinau municipal wastewater treatment plant. The biomass growth of methanogenic microorganisms was carried out in bioreactors within one month under controlled process parameters, with permanent introducing of the nutrition mixture containing sugar and milk (3:1). Microflora cultivation was performed with the periodic cyclic introduction of the substrate. The achievement of $\mathrm{pH}$ 7.4-7.6 and generation of a stable amount of emitted gas has served as indicator of acidophilic process transition to methanogenic in the bioreactor. During the first stage intensive emission of $\mathrm{CO}_{2}$ took place, the liquid in the bulk of bioreactor was acidified due to the acidophilic fermentation. To accelerate the transition process, the nutrition mixture was alkalized with $\mathrm{NaOH}$ to reach $\mathrm{pH}$ 13.0 in 15 days. During the next 20 days, the regime of the nutrition remained 
the same, and $\mathrm{pH}$ in bioreactors was maintained within the range 7.4-7.6. At the same time, the emitted gas volume and composition were measured.

The samples of squalene, netulinole, $\beta$-carotenoid extract and tomatozyde were obtained at our investigation center through isolation from vegetal sources utilizing well-known procedures:

a) squalene - was separated through column chromatography of the unsaponifiable oil extracts from amaranth (Amaranthus cruentus) seeds and further saponification;

b) betulinol - was separated through silica-gel column chromatography of a batch of lupanic compounds extracted with chloroform from the bark of birch trees (Betula pendula);

c) tomatozyde - through extraction with methanol from tomatoes seeds (Licopersiconesculentum) and further precipitation with methanol, gel-filtration and subsequent chromatography on silica-gel columns,

d) extractive preparation of $\beta$-carotene was obtained through extraction with diethyl epher from dry grinded carrots (Carota daura) and cleaning from foreign substances through silica gel filtration.

Sclareol samples were produced by the Institute of Chemistry of the Academy of Sciences of Moldova.

Chemical composition of the periodically collected biogas samples was determined on a portable gas chromatograph.

\section{Conclusions}

The work presented above contains the results of the investigation of the technology of obtaining of biogas through anaerobic fermentation of substrates of liquid agroindustrial wastes such as the marc separated after bioethanol distillation in the presence of phytochemical stimulants of the fermentation. As a result, the intensification of methanogenic fermentation by phytochemical compounds, especially in the case of diterpenoid sclareol, acyclic triterpenic squalene and pentacyclic triterpenoid betulinol added in amounts of $10^{-5}-10^{-3} \%$ by mass of subtrate, an increase of the ratio of emission of biogas by 2-3 times and the increase of methane content in the biogas from $50-60$ to $80 \%$ was achieved.

\section{Acknowledgments:}

The research was performed with financial support of the Science and Technology Center in Ukraine (STCU) and the Academy of Sciences of Moldova in the frameworks of the project STCU No 5393 "Combined Bioreactor with Useful Products and High Efficiency of Biomethane as Alternative Energy Source" (2011-2013) and the project No 5832 "Biochemical stimulation of anaerobic processes and the development of multifunctional reactor to obtaining of the molecular biohydrogen and biomethane" (2013-2015). Authors express their gratitude to the Laboratory of Terpenoides Chemistry (chaired by Acad. Pavel Vlad and Dr. hab. Nicon Ungur) of the Institute of Chemistry of the Academy of Sciences of Moldova for offering the sclareol samples and assistance provided for isolation of squalene, as well as to the Central 
Laboratory of State Inspectorate of Ecology of the Ministry of Environment of the Republic of Moldova for invaluable contribution to chromatographic analysis of the biogas chemical compositions.

\section{References}

1. Cimochowicz-Rybicka M., Zeglin- Curbiel K., Zymon W. Trends in intensification of the anaerobic digestion process at modern wastewater treatment plants. Proc. of Polish-Swedish seminar, report No.9, Stockholm, 2001, pp.1-10.

2. Mindubaev A.Z., Minzanova C.T., Scvortov E.V., Mironov E.B., Zobov, V. V., Ahmadullina F. lu., Mironova L.,G., Belostoțchii D.E., Conovalov A.I. Stimuliruiushcee vlianie suhoi fitomassâ amaranta Amaranthus cruentus na biometanoghenez $v$ trudnofermentiruemâh substratah. Tezisâ docladov $\mathrm{V}$ Vserosiiscoi naucinoi conferenții " Himia i tehnologhia rastitelinâh veshcestv. 2008, p. 206.

3. Malandra L., G. Wolfaardt, A. Zietsman, M. Wiljoen-Bloom. Microbiology of a biological contactor for winery waste water treatment. Water Res. 37, 2003, pp. 412-5.

4. Chiriac V. ș.a. Epurarea apelor uzate şi valorificarea reziduurilor din industria alimentară și zootehnie. Ed. Ceres, București, 1997, 208 pag.

5. Covaliov, V.V., Malina Joseph Francis, Duca Gh., Covaliova O., Bobeica V. Application of Bioactive Substances in the Biogas Tehnology. Management of Water Quality in Moldova (Editor Gh. Duca). Springer, 2014, pp. 225-241.

6. UNIVERSITATEA DE STAT DIN MOLDOVA. Process for anaerobic fermentation of liquid organic waste. Patent of invention MD no.4189. Inventors: COVALIOV, V., BOBEICA, V., UNGUREANU, D., COVALIOVA, O., DUCA, Gh., SENICOVSCAIA, I. Publ. BOPI, 2012, no.12, p.21.

7. UNIVERSITATEA DE STAT DIN MOLDOVA. Combined anaerobic bioreactor for the production of biomethane. Patent of invention MD no 4189.

Inventors:COVALIOV, V., COVALIOVA, O., UNGUREANU, D., NENNO, V., BOBEICA, V., SLIUSARENCO, V., IONETS, I. Publ. BOPI, 2013, no.7, p.2830 . 